\title{
Morphological and Physiological Photon Flux Influence Under in vitro Culture of Apple Shoots
}

\author{
Ilisandra Zanandrea ${ }^{*}$, Marcos Antonio Bacarin', Eugenia Jacira Bolacel Braga ${ }^{2}$, Valmor \\ João Bianchi ${ }^{2}$ and José Antonio Peters ${ }^{2}$ \\ ${ }^{1}$ Programa de Pós-graduação em Agronomia, Fisiologia Vegetal; Universidade Federal de Lavras; 37200-000; \\ Lavras - MG - Brasil. ${ }^{2}$ Programa de Pós-graduação em Fisiologia Vegetal; Departamento de Botânica; Instituto de \\ Biologia; Universidade Federal de Pelotas; Campus Universitário; 96010-900; Pelotas - RS - Brasil
}

\begin{abstract}
The aim of the present study was to evaluate the growth and development of apple rootstock shoots submitted to

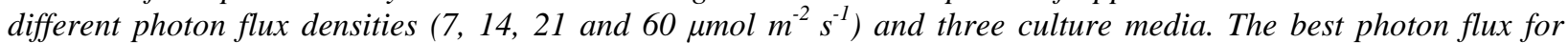
maximizing growth, number of shoots and leaves was $14 \mu \mathrm{mol} \mathrm{m} \mathrm{m}^{-2} \mathrm{~s}^{-1}$, which also resulted in the highest values of chloroplastic pigments. On the other hand, the highest photon flux $\left(60 \mu \mathrm{mol} \mathrm{m} \mathrm{m}^{-1}\right)$ decreased significantly these parameters. Medium with reduced sucrose concentration did not affect the analyzed parameters, enabling an efficient multiplication of the cultivar with only $1 \%$ of sucrose.
\end{abstract}

Key words: Mallus, apple, sucrose, photon flux density, culture medium

\section{INTRODUCTION}

In Brazil, apple tree orchards are usually obtained by grafting plants using a clonal EM (East Malling) rootstock series, and the "M-9" genotype is the most widely rootstock used worldwide (Radmmann, 2001). The use of micropropagation for fruit species results many plants from one single explant, in shorter time than the conventional propagation methods (Magalhães $\mathrm{Jr}$ and Peters, 1991; Schwartz et al., 2000) which, together with meristem culture allows the production of healthy plants and the assurance of genetic stability (Ribas and Zanette, 1992).

The culture medium used in micropropagation should provide nutrients and organic substances necessary for the cellular metabolism and growth factors responsible for differentiation of shoots and roots (Schuch and Peters, 1993; Lombardi et al., 2007). Sucrose is the carbohydrate normally used in culture media (normally 2 to $3 \%$ ) (Flores et al., 1999; Matsumoto et al., 1991; Machado et al., 2004; Feitosa et al., 2007) and the most common sugar in the phloem of angiosperms (Geiger and Servaites, 1991).

Light can also influence the multiplication rate and in vitro growth (Radmann et al., 2001), affecting the photosynthetic processes and the photo morphogenesis by means of quality (wave length), quantity (density of photon flux) and duration (photoperiod) (Kozai et al., 1997; Amaral, 2003).

Until the 1980s, it was considered that in vitro development was strictly heterotrophic. However, Kozai (1991) showed that many in vitro explants have the ability of growing in a photoautotrophic way, with low photosynthetic liquid rate mainly due to low concentration of $\mathrm{CO}_{2}$ the culture flasks

\footnotetext{
*Author for correspondence: dandajs@gmail.com
} 
(Kozai et al., 1991; Le et al., 2001; Mosaleeyanon et al., 2004).

Several authors have highlighted that sugar can have positive (Furbank et al., 1997; Tichá et al., 1998) or negative effects (Hdider and Desjardins, 1994; Serret et al., 1997; Lê et al., 2001) on growth, photosynthesis and photosynthetic gene expression in plants cultured in vitro. The factors that determine such discrepancies are not clear, but it is suggested that negative effects depend on a hypothetical threshold level of sucrose in the leaf (Furbank et al., 1997), the physiological status and/or the development of the plant, or environmental conditions controlling the relation source-drain.

The aim of the present work was to evaluate the growth and development characteristics of shoots of apple tree cultivated in vitro, submitted to different densities of photon flux and to different culture media.

\section{MATERIAL AND METHODS}

Apple rootstock (Malus domestica Borkh) cv. "M9", from in vitro propagation obtained by meristem culture, were used. For initial in vitro multiplication, the explants were inoculated into MS medium (Murashige and Skoog, 1962) with nitrogen concentration reduced to a third. To this medium, $100 \mathrm{mg} \mathrm{L}^{-1}$ of mio-inositol, $30 \mathrm{~g} \mathrm{~L}^{-1}$ of sucrose, $3.5 \mu \mathrm{M}$ of Benzylaminopurine (BAP) (Zanandrea et al., 2006) and $6.0 \mathrm{~g} \mathrm{~L}^{-1}$ of agar, were added. The $\mathrm{pH}$ was adjusted to 5.8 prior to sterilization. The explants consisting of microcuttings with two axilary buds remained in the medium described above for 30 days, in a growth chamber at $25 \pm 2^{\circ} \mathrm{C}$, during the light period and $23 \pm 2^{\circ} \mathrm{C}$ in the dark, photoperiod of $16 \mathrm{~h}$ and photon flux photosynthetically active (FFFA) of $21 \mu \mathrm{mol} \mathrm{m} \mathrm{m}^{-2} \mathrm{~s}^{-1}$.

To set up the experiment, the cultures were submitted to different photon flux photosynthetically active FFFA (7, 14, 21 e 60 $\mu \mathrm{mol} \mathrm{m} \mathrm{m}^{-2} \mathrm{~s}^{-1}$ and the explants inoculated in three culture media, constituted of $10 \mathrm{~g} \mathrm{~L}^{-1}$ of sucrose and $2.2 \mu \mathrm{M}$ of BAP (M1); $30 \mathrm{~g} \mathrm{~L}^{-1}$ of sucrose and $2.2 \mu \mathrm{M}$ of BAP (M2); and $30 \mathrm{~g} \mathrm{~L}^{-1}$ of sucrose and $3.5 \mu \mathrm{M}$ of BAP (M3). Medium M3 was used as control, due to its use for the same rootstock in previous works (Zanandrea et al., 2006). Temperature and photoperiod conditions were the same as the ones previously described and the FFFA were determined by Quantic Sensor, measured in the flasks height. Disposable plastic flasks with lids sterilized by gamma rays were used.

A completely randomized design with a $5 \times 2$ factorial layout, with five replications in each treatment, was employed. Each replication had six explants, totaling 30 explants per treatment. All the experiments were repeated twice. The variables analyzed were the mean of the number of shoots per explant, the length of shoots and the number of leaves per shoot. The chloroplastic pigments (chlorophylls and total carotenoids) which were extracted from the leaves with acetone $80 \%$ by maceration and quantified by spectrophotometry according to Lichtenthaler (1987) were also evaluated.

The statistical analysis was performed by the Statistical Analysis System for Microcomputers SANEST, (Zonta and Machado, 1987) and the means compared by Tukey test. A $\mathrm{P}$ value of $<0.05$ was considered to indicate statistical significance.

\section{RESULTS AND DISCUSSION}

The average number of shoots per explants was not altered when the vegetable material was exposed to 7, 14 and $21 \mu \mathrm{mol} \mathrm{m} \mathrm{m}^{-2}$, regardless of the culture medium used (Table 1). However, when the explants were cultivated under $60 \mu \mathrm{mol}$ $\mathrm{m}^{-2} \mathrm{~s}^{-1}$, there was a significant decrease, in relation to the treatments mentioned above, showing the negative effect of high photon flux on this characteristic, determining a reduction of $43.8 \%$ in the mean number of shootings in relation to the material kept under $21 \mu \mathrm{mol} \mathrm{m} \mathrm{m}^{-2} \mathrm{~s}^{-1}$ (9.61 and 17.09 shoots/explant, respectively) (Fig. $1 \mathrm{G}$ to 1M).

Peters and Magalhães Jr. (1991) observed an increase in the number of shoots in pear explants when submitted to 2000 and 4000 lux. However,

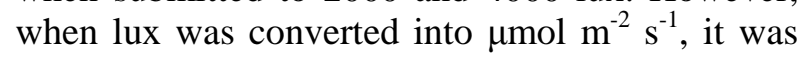
observed that the highest photon flux density used in that work was $48 \mu \mathrm{mol} \mathrm{m} \mathrm{m}^{-2} \mathrm{~s}^{-1}$, well below the highest density used in this work $\left(60 \mu \mathrm{mol} \mathrm{m}^{-2} \mathrm{~s}^{-1}\right)$. 
Table 1 - Average number and length of shoots $(\mathrm{cm})$ per explant of in vitro cultivated apple rootstock in three culture media and under different photon fluxes.

\begin{tabular}{|c|c|c|c|c|c|c|c|c|c|c|}
\hline \multirow{3}{*}{$\begin{array}{l}\text { Culture } \\
\text { Medium }\end{array}$} & \multicolumn{10}{|c|}{ Photon Flux $\left(\mu \mathrm{mol} \mathrm{m} \mathrm{m}^{-2} \mathrm{~s}^{-1}\right)$} \\
\hline & \multicolumn{2}{|c|}{7} & \multicolumn{2}{|c|}{14} & \multicolumn{2}{|c|}{21} & \multicolumn{2}{|c|}{60} & \multicolumn{2}{|c|}{ Means } \\
\hline & number & length & number & length & number & length & number & length & number & length \\
\hline M1 & 18.28 & 1.67 & 10.0 & 1.60 & 16.61 & 1.44 & 8.83 & 0.93 & 13.43 & $1.41^{\mathrm{ab}}$ \\
\hline M2 & 13.44 & 1.47 & 14.17 & 1.48 & 13.28 & 1.14 & 11.44 & 1.0 & 13.08 & $1.27^{\mathrm{b}}$ \\
\hline M3 & 18.78 & 1.65 & 16.44 & 1.82 & 21.39 & 1.45 & 8.56 & 0.87 & 16.29 & $1.45^{\mathrm{a}}$ \\
\hline Mean & $16.83^{\mathrm{A}}$ & $1.60^{\mathrm{A}}$ & $13.54^{\mathrm{AB}}$ & $1.63^{\mathrm{A}}$ & $17.09^{\mathrm{A}}$ & $1.34^{\mathrm{B}}$ & $9.61^{\mathrm{B}}$ & $0.93^{\mathrm{C}}$ & & \\
\hline
\end{tabular}

Means followed by the same letter in the same parameters (capital letter in the line and lower case in the column) did not show significant difference at the $5 \%$ level of probability by Tukey test. M1: MS $+10 \mathrm{~g} \mathrm{~L}^{-1}$ sucrose $+2.2 \mu \mathrm{M} \mathrm{BAP} ; \mathrm{M} 2: \mathrm{MS}+30 \mathrm{~g} \mathrm{~L}^{-1}$ sucrose $+2.2 \mu \mathrm{M}$ BAP; $\mathrm{M} 3: \mathrm{MS}+30 \mathrm{~g} \mathrm{~L}^{-1}$ sucrose $+3.5 \mu \mathrm{M}$ BAP.

According to these authors, the results obtained could be explained by the interaction between the light regiment and endogenous auxin content, once higher photon flux densities could reduce the endogenous AIA shoots concentration, through photo-oxidation, leading to a displacement of the hormonal balance towards the cytokinin, which would increase the multiplication rate. The culture media used did not affect the average number of shoots per explants, regardless the cytokinin or the sucrose concentration present in the respective media (Table 1). As mentioned in the methodology, M3 medium usually used for the multiplication of this rootstock (Zanandrea et al., 2006), presented higher concentration of BAP in relation to M1 and M2 media. The use of M1 and M2 media, with different BAP concentrations was due to the need for shootings with leaves with larger area, which would be used for studies of the photosynthetic apparatus. These results differed from the ones obtained by Abreu and Pedrotti (2003) who observed higher number of shoots of Malus platycarpa when cultivated in $2.2 \mu \mathrm{M}$ of BAP and $30 \mathrm{~g}$ of sucrose.

The same was observed in relation to the quantities of sucrose used in the present work. There was no variation in the average number of shoots per explants, in the presence of 10 (M1) or $30 \mathrm{~g} \mathrm{~L}^{-1}$ of sucrose (M2 and M3), regardless the concentration of BAP (Table 1). Reports in the literature have emphasized the influence of sucrose concentration in the in vitro development. Working with the same species, Lux-Endrich et al. (2000) obtained higher proliferation of shoots with $40 \mathrm{~g} \mathrm{~L}^{-1}$ of sucrose in comparison to 10, 20 and 60 $\mathrm{g} \mathrm{L}^{-1}$. Chong and Pua (1985), working with another apple rootstock "Ottawa 3", obtained higher average number of shoots with $30 \mathrm{~g} \mathrm{~L}^{-1}$ of sucrose. This variation in the response to the sucrose concentration in the culture media has been observed in other species, such as almond tree. Hisajima (1982) and Rugini and Verma (1983) observed that concentrations between 30 and $40 \mathrm{~g} \mathrm{~L}^{-1}$ allowed better rates of production of shoots. Similar results were obtained by Gürel and Gülsen (1998), studying in vitro production of shoots of Amygdalus communis, highlighting though that $20 \mathrm{~g} \mathrm{~L}^{-1}$ of sucrose determined lower number of shoots per explant. Silva et al. (2003) observed a high rate of multiplication in Prunus, with $20 \mathrm{~g} \mathrm{~L}^{-1}$ of sucrose.

In the present work high multiplication rate (number of shoots per explant) was observed, independent of the medium used (Table 1). There was a reduction of this parameter only when the cultures were exposed to a higher photon flux density $\left(60 \mu \mathrm{mol} \mathrm{m} \mathrm{m}^{-2} \mathrm{~s}^{-1}\right)$. Considering that in vitro responses were dependent on the genotype (Silva et al., 2003), the best results obtained (between 13.54 and 17.09 shoots per explant) were similar to those reported by Schuch and Peters (1993) that obtained 19.13 and 16.07 shoots per explant in Marubakaido and Megumi apple rootstocks, respectively.

As could be observed in Table 1, the shootings length was influenced by the photon flux density and by the culture media (Fig. 1). The highest lengths were obtained with 7 and $14 \mu \mathrm{mol} \mathrm{m} \mathrm{m}^{-1}$, which differed significantly from the other lengths. The highest reduction in the shootings length $(41.9 \%)$ was obtained when they were cultivated in $60 \mu \mathrm{mol} \mathrm{m} \mathrm{m}^{-2} \mathrm{~s}^{-1}$, when compared to the two lower light levels. Among the media used, M2 medium with $30 \mathrm{~g} \mathrm{~L}^{-1}$ of sucrose and $2.2 \mu \mathrm{M}$ of BAP induced significantly shorter length of shootings in relation to the other two media. These results differed from the ones obtained by Abreu and Pedrotti (2003), who observed that different BAP concentrations did not influence the height of the shoots of apple rootstock cv. "M-9". 


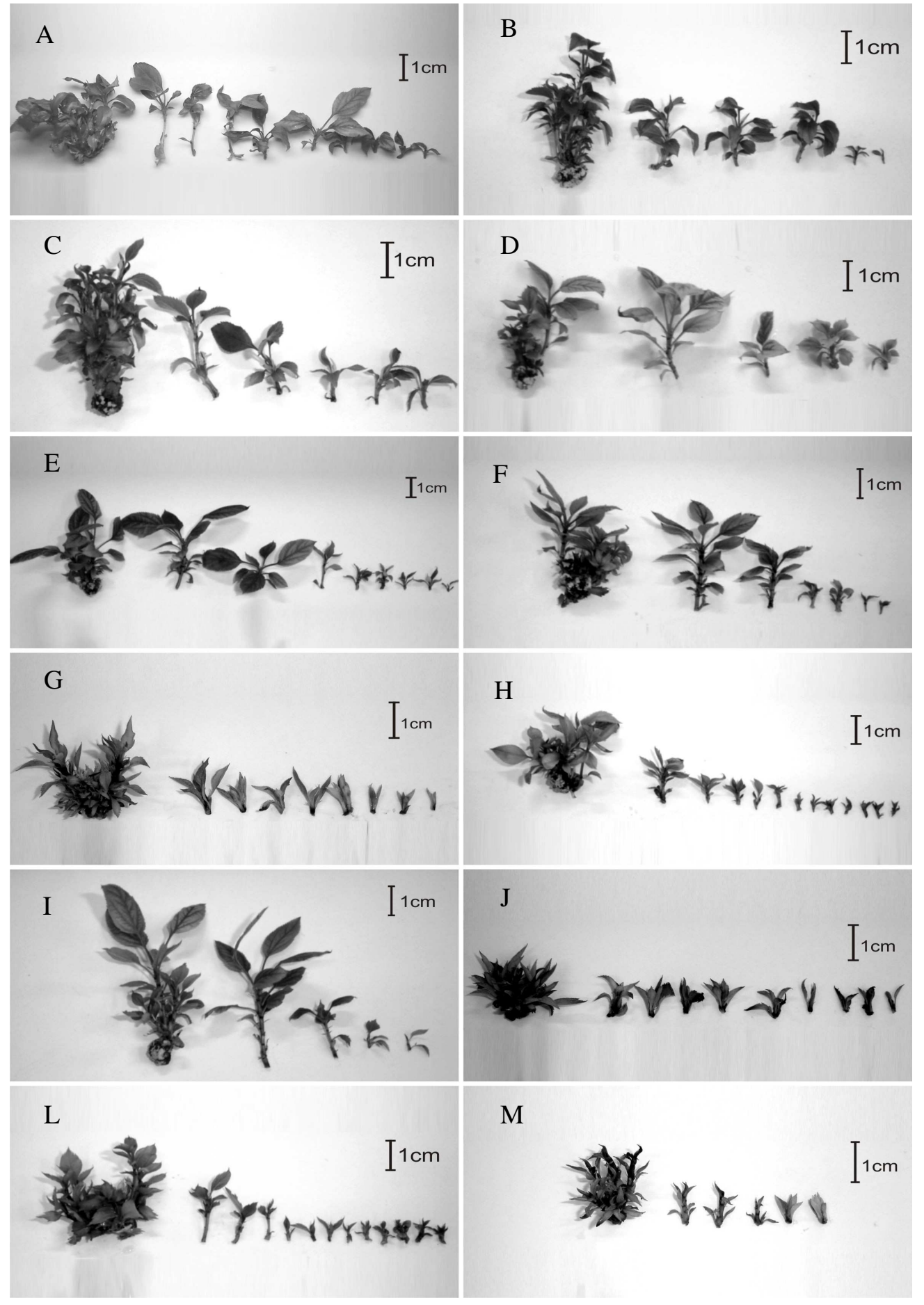

Figure 1 - Apple (cv. M9) shoots multiplication in vitro cultivated; A) 10 g sucrose, $2.2 \mu \mathrm{M}$ BAP and FFFA of $7 \mu \mathrm{mol} \mathrm{m} \mathrm{m}^{-2} \mathrm{~s}^{-1}$; B) $30 \mathrm{~g}$ sucrose, $2.2 \mu \mathrm{M}$ BAP and FFFA of $7 \mu \mathrm{mol} \mathrm{m}^{-2} \mathrm{~s}^{-1}$; C) $30 \mathrm{~g}$ sucrose, $3.5 \mu \mathrm{M}$ BAP and FFFA of $7 \mu \mathrm{mol} \mathrm{m}^{-2} \mathrm{~s}^{-1}$; D) $10 \mathrm{~g}$ sucrose, $2.2 \mu \mathrm{M}$ BAP and FFFA of $14 \mu \mathrm{mol} \mathrm{m} \mathrm{m}^{-1}$; E) $30 \mathrm{~g}$ sucrose, $2.2 \mu \mathrm{M}$ BAP and FFFA of $14 \mu \mathrm{mol} \mathrm{m} \mathrm{m}^{-2}$; F) $30 \mathrm{~g}$ sucrose, $3.5 \mu \mathrm{M}$ BAP and FFFA of $14 \mu \mathrm{mol} \mathrm{m} \mathrm{m}^{-2} \mathrm{~s}^{-1}$; G) $10 \mathrm{~g}$ sucrose, $2.2 \mu \mathrm{M}$ BAP and FFFA of $21 \mu \mathrm{mol} \mathrm{m} \mathrm{s}^{-1}$; H) $30 \mathrm{~g}$ sucrose, $2.2 \mu \mathrm{M}$ BAP and FFFA of $21 \mu \mathrm{mol} \mathrm{m}^{-2} \mathrm{~s}^{-1}$; I) 30 g sucrose, $3.5 \mu \mathrm{M}$ BAP and FFFA of $14 \mu \mathrm{mol} \mathrm{m} \mathrm{m}^{-2} \mathrm{~s}^{-1}$; J) $10 \mathrm{~g}$ sucrose, $2.2 \mu \mathrm{M}$ BAP and FFFA of $60 \mu \mathrm{mol} \mathrm{m} \mathrm{m}^{-2} \mathrm{~s}^{-1}$; L) $30 \mathrm{~g}$ sucrose, $2.2 \mu \mathrm{M}$ BAP and FFFA of $60 \mu \mathrm{mol} \mathrm{m}^{-2} \mathrm{~s}^{-1}$; M) $30 \mathrm{~g}$ sucrose, $3.5 \mu \mathrm{M}$ BAP and FFFA of $60 \mu \mathrm{mol} \mathrm{m} \mathrm{m}^{-2} \mathrm{~s}^{-1}$. 
Studies carried out by Fuentes et al. (2005), with in vitro growth of cocoanut, showed that plants developed under low concentration of exogenous sucrose were bigger than the ones developed in medium with high concentrations of sucrose, when submitted to low FFFA $\left(40 \mu \mathrm{mol} \mathrm{m} \mathrm{m}^{-2} \mathrm{~s}^{-1}\right)$; but under $400 \mu \mathrm{mol} \mathrm{m} \mathrm{m}^{-2} \mathrm{~s}^{-1}$, there was a marked decrease in the height, independent of the sucrose concentration. Flores et al. (1999), studying shoots growth of the apple rootstock cv. Marubakaido, did not observe significant effect regarding sucrose concentrations, although $45 \mathrm{~g} \mathrm{~L}^{-1}$ allowed a higher mean growth of the shoots. As pointed out in relation to the number of shootings, in vitro growth was also dependent on the genotype (Silva et al., 2003).

Regarding the number of leaves per shooting (Table 2), it was observed that the treatment with $14 \mu \mathrm{mol} \mathrm{m} \mathrm{m}^{-2} \mathrm{~s}^{-1}$ was statistically higher than the other treatments, with a significant reduction when used $60 \mu \mathrm{mol} \mathrm{m} \mathrm{m}^{-2} \mathrm{~s}^{-1}$, in spite of the culture medium used.

Table 2 - Average number of leaves per shooting of in vitro cultivated apple rootstock in three culture media and under different photon fluxes.

\begin{tabular}{cccccc}
\hline Culture & \multicolumn{5}{c}{ Photon flux density $\left(\boldsymbol{\mu m o l ~ \mathbf { ~ m } ^ { - 2 } \mathbf { s } ^ { - \mathbf { 1 } } )}\right.$} \\
\cline { 2 - 6 } medium & 7 & 14 & 21 & 60 & Mean \\
\hline M1 & 5.50 & 7.70 & 6.17 & 4.09 & 5.87 \\
M2 & 6.70 & 6.97 & 5.68 & 4.69 & 6.01 \\
M3 & 6.58 & 6.85 & 5.50 & 4.27 & 5.80 \\
\hline Mean & $6.26^{\mathrm{B}}$ & $7.18^{\mathrm{A}}$ & $5.79^{\mathrm{B}}$ & $4.35^{\mathrm{C}}$ & \\
\hline
\end{tabular}

Mean followed by the same capital letter in the line did not show significant difference at the $5 \%$ level of probability by Tukey test. M1: MS + $10 \mathrm{~g} \mathrm{~L}^{-1}$ sucrose $+2.2 \mu \mathrm{M}$ BAP; $\mathrm{M} 2: \mathrm{MS}+30 \mathrm{~g} \mathrm{~L}^{-1}$ sucrose $+2.2 \mu \mathrm{M}$ BAP; $\mathrm{M} 3: \mathrm{MS}+30 \mathrm{~g} \mathrm{~L}^{-1}$ sucrose $+3.5 \mu \mathrm{M}$ BAP.

Different from the results reported by Ambrósio and Melo (2004) and Pasqual et al. (1991) who observed a reduction in the number of leaves of other species when the sucrose concentration was increased in the culture media, significant difference was not observed in the concentrations used in the present work. However, Fuentes et al. (2005) noted that the number of cocoanut leaves was negatively affected only when the cultures were submitted to extreme concentrations of sucrose $\left(0\right.$ or $\left.90 \mathrm{~g} \mathrm{~L}^{-1}\right)$. It was also observed that the decrease in BAP concentration did not affect the average number of leaves per shoots (Table 2). Visual observations showed that shoots cultivated under lower photon flux $\left(7 \mu \mathrm{mol} \mathrm{m} \mathrm{m}^{-2} \mathrm{~s}^{-1}\right)$ presented thinner and more flexible stems in relation to other treatments, which had more rigid and thicker stems. Similar results were observed by Radmann et al. (2001), working with in vitro propagation of Gypsophila paniculata under different photon flux.

In relation to chloroplastic pigments (Table 3), it was observed that despite the culture media used, the total chlorophyll content was low under $7 \mu \mathrm{mol}$ $\mathrm{m}^{-2} \mathrm{~s}^{-1}$, increasing under $14 \mu \mathrm{mol} \mathrm{m} \mathrm{m}^{-2} \mathrm{~s}^{-1}$, and decreasing again under the other photon fluxes used. In the treatment with $60 \mu \mathrm{mol} \mathrm{m} \mathrm{m}^{-2} \mathrm{~s}^{-1}$, the content of this pigment was drastically reduced in relation to the other treatments, which was, $33.3 \%$ lower than the treatment with $14 \mu \mathrm{mol} \mathrm{m} \mathrm{m}^{-2} \mathrm{~s}^{-1}(0.31$ and $0.93 \mathrm{mg} \mathrm{g}^{-1} \mathrm{MF}$, respectively).

Serret et al. (2001), working with gardenia plants (Gardenia jasminoides) repeated the values between 0.75 and $1.36 \mathrm{mg} \mathrm{g}^{-1}$ MF of chlorophyll according to the light level to which the cultures were exposed (50 and $100 \mu \mathrm{mol} \mathrm{m} \mathrm{m}^{-2}$ ). They also observed a decrease in the content of chlorophyll with the increase of light incidence. Similarly, Nicotiana tabacum plants cultivated in vitro under $380 \mu \mathrm{mol} \mathrm{m} \mathrm{m}^{-2} \mathrm{~s}^{-1}$ presented a significantly lower content of total chlorophyll than under $80 \mu \mathrm{mol} \mathrm{m}$ ${ }^{2} \mathrm{~s}^{-1}$, regardless of the sucrose concentration used in the medium (Kadlecek et al., 2003). Contrary to these results, Serret et al. (2001) also reported an increase in the content of total chlorophyll with the increase of the sucrose concentration in the culture media.

Regarding carotenoid content (Table 3), significant interaction was observed between the factors tested (culture media and photon flux density). M2 medium, under $60 \mu \mathrm{mol} \mathrm{m}{ }^{-2} \mathrm{~s}^{-1}$ and M1 under $14 \mu \mathrm{mol} \mathrm{m} \mathrm{m}^{-2} \mathrm{~s}^{-1}$ presented the lowest $\left(0.08 \mathrm{mg} \mathrm{g}^{-1} \mathrm{MF}\right)$ and the highest $\left(0.33 \mathrm{mg} \mathrm{g}^{-1} \mathrm{MF}\right)$ carotenoid content, respectively. It was also observed that similarly to chlorophylls, carotenoid content increased up to $14 \mu \mathrm{mol} \mathrm{m} \mathrm{m}^{-2} \mathrm{~s}^{-1}$, decreasing with higher photon fluxes. 
Table 3 - Average content of total chlorophyll ( $\left.\mathrm{mg} \mathrm{g}^{-1} \mathrm{MF}^{*}\right)$ and carotenoid content $\left(\mathrm{mg} \mathrm{g}^{-1} \mathrm{MF}^{*}\right)$ of leaves from in vitro cultivated apple shootings in three culture media and under different photon fluxes.

\begin{tabular}{|c|c|c|c|c|c|c|c|c|}
\hline \multirow[t]{3}{*}{$\begin{array}{l}\text { Culture } \\
\text { medium }\end{array}$} & \multicolumn{8}{|c|}{ Photon Flux $\left(\mu \mathrm{mol} \mathrm{m} \mathrm{m}^{-2} \mathrm{~s}^{-1}\right)$} \\
\hline & \multicolumn{2}{|c|}{7} & \multicolumn{2}{|c|}{14} & \multicolumn{2}{|c|}{21} & \multicolumn{2}{|c|}{60} \\
\hline & chl** & $\operatorname{car}^{* * * *}$ & chl** & car**** & chl** & car*** & chl** & car**** \\
\hline M1 & 0.66 & $0.20^{\mathrm{aB}}$ & 1.10 & $0.33^{\mathrm{aA}}$ & 0.57 & $0.17^{\mathrm{aBC}}$ & 0.28 & $0.12^{\mathrm{abc}}$ \\
\hline M2 & 0.73 & $0.19^{\mathrm{aA}}$ & 0.82 & $0.21^{\mathrm{bA}}$ & 0.61 & $0.17^{\mathrm{aA}}$ & 0.28 & $0.08^{\mathrm{bB}}$ \\
\hline M3 & 0.67 & $0.21^{\mathrm{aAB}}$ & 0.86 & $0.24^{\mathrm{bA}}$ & 0.62 & $0.14^{\mathrm{aC}}$ & 0.36 & $0.14^{\mathrm{aBC}}$ \\
\hline Mean & $0.69^{\mathrm{B}}$ & 0.20 & $0.93^{A}$ & 0.26 & $0.60^{\mathrm{B}}$ & 0.16 & $0.31^{\mathrm{C}}$ & 0.11 \\
\hline
\end{tabular}

Means followed by the same letter in the same parameters (capital letter in the line and lower case in the column) did not show significant difference at the $5 \%$ level of probability by Tukey test. M1: MS $+10 \mathrm{~g} \mathrm{~L}^{-1}$ sucrose $+2.2 \mu \mathrm{M}$ BAP; M2: MS $+30 \mathrm{~g} \mathrm{~L}-1$ sucrose $+2.2 \mu \mathrm{M}$ BAP; $\mathrm{M} 3: \mathrm{MS}+30 \mathrm{~g} \mathrm{~L}^{-1}$ sucrose $+3.5 \mu \mathrm{M}$ BAP.

$* \mathrm{MF}-$ fresh matter; $* * \mathrm{chl}=$ Chlorophyll; $* * * \mathrm{car}=$ carotenoids

It was observed that with $60 \mu \mathrm{mol} \mathrm{m} \mathrm{m}^{-2} \mathrm{~s}^{-1}$, the shoots had a reddish color in all multiplication media tested (Fig. $1 \mathrm{~J}$ to $1 \mathrm{M}$ ), while in the other treatments, the plants had an intense green color, especially with 7 and $14 \mu \mathrm{mol} \mathrm{m} \mathrm{m}^{-2} \mathrm{~s}^{-1}$ regardless of the culture medium tested (Figura 1A a $1 \mathrm{~F}$ ). By visual observations, Lux-Endrich et al. (2000) observed a light green color in apple tree shoots cultivated in media with 0.0 and $10.0 \mathrm{~g} \mathrm{~L}^{-1}$ of sucrose; the addition of $20 \mathrm{~g} \mathrm{~L}^{-1}$ of sucrose resulted in green color, whereas $40 \mathrm{~g} \mathrm{~L}^{-1}$ induced green leaves and reddish shoots and $60 \mathrm{~g} \mathrm{~L}^{-1}$ resulted in red color of shoots and leaves.

The low concentration of sucrose (M1 medium) did no affect negatively the content of chloroplastidic pigments (Table 3), or the color of leaves and stems of the shootings (Figs. 1A to 1I). However, this effect was clear when the cultures were exposed to photon flux density of $60 \mu \mathrm{mol} \mathrm{m}$ ${ }^{2} \mathrm{~s}^{-1}$, regardless of the sucrose and BAP concentrations (Fig. $1 \mathrm{~J}$ to $1 \mathrm{M}$ ).

The results indicated that the increase of photon flux could have influenced the biosynthesis and/or the degradation of chlorophylls and carotenoids. The change in the content of photosynthetic pigments might result in a decrease in the capture of light by the light-harvesting complex of the photo system I (LHC I) and photosystem II (LHC II) and in the capacity of electrons transference in the photosynthetic chain (Kadlecek et al., 2003). Pandey et al., (2006) observed that Anoectochilus plants, acclimatized under high irradiance (300 $\mu \mathrm{mol} \mathrm{m} \mathrm{m}^{-2} \mathrm{~s}^{-1}$ ) showed a reduction in the content of chlorophylls $a$ and $b$ and $\beta$-carotenes due to the excess of photons absorbed, resulting in the degradation of the photosynthetic machinery and/or reduction of size of the light-harvesting complex, suggesting that interconversions between chlorophylls $a$ and $b$ were important for the establishment of an adequate $a / b$ chlorophyll rate during the adaptation of leaves to low and high irradiance.

\section{CONCLUSION}

High photon flux decreased the number of shootings and leaves, as well as the shootings length. The best photon flux to maximize growth, number of shootings and leaves, as well as the chloroplastidic pigments of apple rootstock, cv. "M-9", is $14 \mu \mathrm{mol} \mathrm{m} \mathrm{m}^{-2} \mathrm{~s}^{-1}$, and $1 \%$ of sucrose allows an efficient multiplication of this cultivar.

\section{RESUMO}

O objetivo do presente estudo foi avaliar características de crescimento e desenvolvimento de brotações de macieira submetidas a diferentes densidades de fluxo de fótons $(7,14,21$ e $60 \mu \mathrm{mol}$ $\mathrm{m}^{-2} \mathrm{~s}^{-1}$ ) e três meios de cultura. O melhor fluxo de fótons para maximizar o crescimento, número de brotações e de folhas foi de $14 \mu \mathrm{mol} \mathrm{m} \mathrm{m}^{-2}$, o qual também proporcionou os maiores valores de pigmentos cloroplastídicos. Por outro lado, alto fluxo de fótons $\left(60 \mu \mathrm{mol} \mathrm{m}^{-2} \mathrm{~s}^{-1}\right)$ diminuiu significativamente os parâmetros citados acima. $\mathrm{O}$ meio com concentração reduzida de sacarose não afetou os parâmetros analisados, possibilitando uma multiplicação eficiente desta cultivar com apenas $1 \%$ deste carboidrato. 


\section{REFERENCES}

Abreu, M. F.; Pedrotti, E. L. (2003), Micropropagação de macieira. Revista Biotecnologia Ciência \& Desenvolvimento, 31, 100-108.

Amaral, A. F. C. (2003), Comportamento in vitro de matrizes de cenoura (Daucus carota L.) tratadas com variáveis níveis de Potássio. Dissertação de Mestrado, Piracicaba, São Paulo.

Ambrósio, S. T.; Melo, N. F. (2004), Interaction between sucrose and $\mathrm{pH}$ during in vitro culture of Nephrolepis biserrata (Sw.) Schott (Pteridophyta). Acta Botânica Brasileira, 18, 809-813.

Chong, C.; Pua, E. C. (1985), Carbon nutrition of Ottawa 3 apple rootstock during stages of in vitro propagation. Journal of Horticultural Science, 60, 285-290.

Feitosa, T.; Bastos, J. L. P.; Ponte, L. F. A.; Jucá, T. L.; Campos, F. A. P. (2007), Somatic Embryogenesis in Cassava Genotypes from the Northeast of Brazil. Brazilian Archives of Biology and Technology, 50, 201-206.

Flores, R.; Lessa, A. O.; Peters, J. A.; Fortes, G. R. L. (1999), Efeito da sacarose e do benomyl na multiplicação in vitro da macieira. Pesquisa Agropecuária Brasileira, 34, 2363-2368.

Fuentes, G.; Talavera, C.; Desjardins, Y.; Santamaria, J. M. (2005), High irradiance can minimize the negative effect of exogenous sucrose on the photosynthetic capacity of in vitro grown coconut plantlets. Biologia Plantarum, 49, 7-15.

Furbank, R. T.; Pritchard, J.; Jenkins, C. L. D. (1997), Effects of exogenous sucrose feeding on photosynthesis in the C3 plant tobacco and the $\mathrm{C} 4$ plant Flaveria bidentis. Australian Journal of Plant Physiology, 24, 291-299.

Geiger, D. R.; Servaites, J. C. (1991), Carbon allocation and response to stress, In-Response of plants to multiple stresses, ed. William Winner; Eva Pell; Jacques Roy. Academic Press, New York, pp. 103127.

George, E. F.; Sherrington, P. D. (1984), Plant Propagation by Tissue Culture. Exegetics, London, $709 \mathrm{p}$.

Gürel, S.; Gülsen, Y. (1998), The effects of different sucrose, agar and $\mathrm{pH}$ levels on in vitro shoot production of almond (Amygdalus communis L.) Turkish Journal of Botany, 22, 363-373.

Hdider, C.; Desjardins, Y. (1994), Effects of sucrose on photosynthesis and phosphoenolpyruvate carboxylase activity of in vitro cultured strawberry plantlets. Plant Cell, Tissue and Organ Culture, 1, 27-33.

Hisajima S. (1982), Multiple shoot formation from almond embryos. Biology Plantarum, 24, 235-238.

Kadlecek, P.; Rank, B.; Tichá, I. (2003), Photosynthesis and photoprotection in Nicotiana tabacum L. in vitro grown plantlets. Journal of Plant Physiology, 160, 1017-1024.
Kozai, T. Micropropagation under photoautotrophic conditions. (1991), In- Micropropagation: technology and application, ed. Debergh, P. C.; Zimmerman, R. H., Kluwer Academic, Amsterdan, pp. 447-469.

Kozai, T.; Iwabuchi, K.; Watanabe, K.; Watanabe, I. (1991), Photoautotrophic and photomixotrophic growth of strawberry plantlets in vitro and changes in nutrient composition of the medium. Plant Cell, Tissue and Organ Culture, 25, 107-115,

Kozai, T.; Kubota, C.; Jeong, B. R. (1997), Environmental control for the large-scale production of plants through in vitro techniques. Plant Cell, Tissue and Organ Culture, 51, 49-56.

Le, V. Q.; Samson, G.; Desjardins, Y. (2001), Opposite effects of exogenous sucrose on growth, photosynthesis and carbon metabolism of in vitro plantlets of tomato (L. esculentum Mill.) grown under two levels of irradiances and $\mathrm{CO}_{2}$ concentration. Journal of Plant Physiology, 158, 599-605.

Lichtenthaler, H. K. (1987), Chlorophylls and carotenoids: pigments of photosynthetic biomembranes. In- Methods in enzymology, ed. Packer, L.; Douce, R. Academic Press, New York, v.148, pp.350-382.

Lombardi S. P.; Silva, I. R.; Nogueira M. C. S.; Appezzato-da-Glória B. (2007), In vitro Shoot Regeneration from Roots and Leaf Discs of Passiflora cincinnata Mast. Brazilian Archives of Biology and Technology, 50, 239-247.

Lux-Endrich, A.; Treutter, D.; Feucht, W. (2000), Influence of nutrients and carbohydrate supply on the phenol composition of apple shoot cultures. Plant Cell, Tissue and Organ Culture, 60, 15-21.

Machado, M. P.; Carvalho, D. C.; Biasi, L. A. (2004), Multiplicação in vitro do porta-enxerto de macieira'marubakaido' em diferentes meios de cultivo e concentrações de ácido giberélico. Scientia Agraria, 5, 69-72.

Magalhães Jr, A. M.; Peters, J. A. (1991), Cultura "in vitro" de ameixeira: efeito do Ácido Indolbutírico, tipo de lâmpada e intensidade luminosa no enraizamento. Revista Brasileira de Fisiologia Vegetal, 3, 57-61.

Matsumoto, K.; Cabral, G. B.; Teixeira, J. B.; Rech, E. L. (1991), Embriogênese somática a partir de folhas imaturas de mandioca in vitro. Revista Brasileira de Fisiologia Vegetal, 3, 107-110.

Mosaleeyanon, K.; Cha-Um, S.; Kirdmanee, C. (2004), Enhanced growth and photosynthesis of rain tree (Samanea saman Merr.) plantlets in vitro under a $\mathrm{CO}_{2}$-enriched condition with decreased sucrose concentrations in the medium. Scientia Horticulturae, 103, 51-63.

Murashige, T.; Skoog, F. (1962), A revised medium for rapid growth and bioassay with tobacco tissue culture. Physiologia Plantarum, 15, 473-497. 
Pandey, D. M.; Yu, K. W.; Wu, R. Z. Hahn, E. J.; Paek, K. Y. (2006), Effects of different irradiances on the photosynthetic process during ex-vitro acclimation of Anoectochilus plantlets. Photosynthetica, 44, 419424.

Pasqual, M.; Lopes, P. A.; Arello, E. F.; Barros, I. (1991), Influência de 6-Benzilaminopurina, sacarose e ágar sobre a vitrificação de brotos de pereira in vitro. Pesquisa Agropecuária Brasileira, 26, 19191924.

Peters, J. A.; Magalhães Jr. A. M. (1991), Efeito do meio de cultura, tipo de lâmpada e intensidade de luz na multiplicação in vitro de ameixeira. Revista Brasileira de Fruticultura, 13, 41-48.

Radmann, E. B. (2001), Efeito de fitoreguladores e condições de cultivo no enraizamento in vitro de porta-enxertos de macieira 'M-9'. Disssertação de mestrado, Universidade Federal de Pelotas, Pelotas, Brasil.

Radmann, E. B.; Braga, E. J. B.; Karan, M. A. L.; Posada, M. A. C.; Peters, J. A. (2001), Influência da densidade de fluxo luminoso na qualidade de plantas micropropagadas de Gypsophila paniculata L. Revista Brasileira de Agrociência, 7, 171-175.

Ribas, L. L.; Zanette, F. (1992), Propagação da macieira cv. Gala através da cultura de meristemas. Revista Brasileira de Fisiologia Vegetal, 4, 39-43.

Rugini E., Verma D. C. (1983), Micropropagation of a difficult to propagate almond (Prunus amygdalus Batsch) cultivar. Plant Science Letters, 28, 273-281.

Schuch, M. W.; Peters, J. A. (1993), Multiplicação in vitro de brotações de macieira cultivares Marubakaido (Malus prunifolia, Willd, Borkh) e Megumi (Malus domestica, Borkh). Pesquisa Agropecuária Brasileira, 28, 433-437.

Schwartz, E.; Roncatto, G.; Fortes, G. R. L. (2000), Multiplicação in vitro do porta-enxerto de macieira cv. Marubakaido utilizando 6-Benzilaminopurina e Ácido Naftalenoacético. Revista Brasileira de Fruticultura, 22, 77-79.

Serret, M. D.; Trillas, M. I.; Matas, J.; Araus, J. L. (1997), Development of photoautotrophy and photoinhibition of Gardenia jasmoides plantlets during micropropagation. Plant Cell, Tissue and Organ Culture, 45, 1-16.

Serret, M. D.; Trillas, M. I.; Araus, J. L. (2001), The effect of in vitro conditions on the pattern of photoinhibition during acclimation of gardenia plantlets to ex vitro conditions. Photosynthetica, 39, 67-73.

Silva, A. L.; Rogalski, M.; Moraes , L. K. A.; Feslibino, C.; Crestani, L.; Guerra, M. P. (2003), Estabelecimento e multiplicação in vitro de portaenxertos de Prunus Revista Brasileira de Fruticultura, 25, 297-300.

Tichá, I.; Cáp, F.; Pacovská, D.; Hofman, P.; Haisel, D.; Capková, V.; Schäfer, C. (1998), Culture on sugar medium enhances photosynthetic capacity and high light resistance of plantlets grown in vitro. Physiology Plantarum, 102, 155-162.

Zanandrea, I.; Bacarin, M. A.; Schmitz, D. D.; Braga, E. J. B.; Peters, J. A. (2006), Chlorophyll fluorescence in in vitro cultivated apple. Revista Brasileira de Agrociência, 12, 305-308.

Zonta, E. P.; Machado, A. A. (1987), SANEST Sistema de análise estatística para microcomputadores. Pelotas: DMEC/IFM/ UFPel, 138.

Received: April 17, 2006; Revised: November 08, 2007; Accepted: November 10, 2008. 